\title{
UPAYA PERSATUAN PELAJAR KELUARGA BESAR MUSTHAFAWIYAH SIBANGGOR JAE DALAM MENINGKATKAN LIFE SKILL SANTRI DI PONDOK PESANTREN MUSTHAFAWIYAH PURBA BARU
}

\author{
Oleh:
}

\section{Muhammad Roihan Daulay ${ }^{1}$}

\begin{abstract}
Abstrak
Rumusan masalah dalam penelitian ini adalah apa saja life skill santri yang ada di persatuan, apa saja upaya yang dilakukan, dan apa kendala yang dihadapi persatuan pelajar keluarga besar Musthafawiyah Sibanggor Jae dalam meningkatkan life skill santri di Pondok Pesantren Musthafawiyah Purba Baru. Penelitian ini bertujuan untuk mengetahui apa saja life skill santri, upaya yang dilakukan, dan kendala yang dihadapi persatuan pelajar keluarga besar Musthafawiyah Sibanggor Jae dalam meningkatkan life skill santri di Pondok Pesantren Musthafawiyah Purba Baru. Penelitian ini mengunakan pendekatan kualitatif yang bersifat eksploratif. Adapun informan yang diteliti dalam penelitian ini adalah seluruh struktur organisasi persatuan pelajar keluarga besar Musthafawiyah Sibanggor Jae yang berjumlah 12 orang. Penelitian ini menyimpulkan bahwa, Life skill yang ada di persatuan keluarga besar Musthafawiyah Sibanggor Jae ada empat yaitu puisi, pidato, tilawatil Quran, dan barzanji. Life skill yang di bentuk di persatuan ini merupakan life skill yang bersifat khusus yaitu kecakapan vocasiona, kecakapan vocasional adalah kecakapan yang terkait keterampilan melakukan suatu pekerjaan yang ingin ditekuni.Upaya yang dilakukan persatuan pelajar keluarga besar Musthafawiyah Sibanggor Jae dalam meningkatkan life skill santri, yaitu: Pertama, disiplin santri berjalan dengan baik, hal ini dapat di lihat dari ketepatan waktu para anggota dan juga dari absensi atau kehadiran para anggota dalam meningkatkan kegiatan-kegiatan yang telah ditetapkan dalam persatuan. Kedua, latihan yang dilaksanakan berjadwal sesuai dengan yang telah ditetapkan dalam persatuan. Ketiga, motivasi dengan cara memberikan hadiah, penghargaan, pujian dan hukuman. Sedangkan kendala-kendala yang dihadapi persatuan
\end{abstract}

${ }^{1}$ Penulis adalah Dosen Fakultas Tarbiyah dan Ilmu Keguruan IAIN Padangsidimpuan 
pelajar keluarga besar Musthafawiyah Sibanggor Jae dalam meningkatkan life skill santri ada dua faktor, yaitu: faktor internal banyaknya santri yang ngomong-ngomong dan asik bercerita ketika temannya menyampaikan isi puisi, pidato, dan pembacaan tilawatil Quran, kurangnya keaktifan santri dalam mengikuti kegiatan-kegiatan, kurangnya minat dan motivasi santri dalam mengembangkan potensi yang ada pada dirinya. Faktor eksternal yang berasal dari luar diri santri yaitu dari staf persatuan kurang mampunya staf persatuan dalam memotivasi santri/anggota, kurangnya kerja sama yang baik di antara staf-staf persatuan sehingga terkadang ada anggapan bahwa kegiatan dalam meningkatkan life skill santri hanya tanggungjawab ketua persatuan saja.

Keywords: Persatuan pelajar, musthafawiyah, dan life skill santri

\section{Pendahuluan}

\section{Latar Belakang Masalah}

Ketua persatuan sama dengan pemimpin organisasi, ketua persatuan itu istilah yang dipakai dalam setiap struktur persatuan di Pondok Pesantren Musthafawiyah. Di dalam setiap organisasi ada beberapa gabungan dari desa, kecamatan dan kabupaten.

Dalam perkembangannya organisasi banyak terbentuk dengan berbagai macam dan bentuk yang berbeda-beda. Salah satunya adalah organisasi yang dibentuk di Musthafawiyah yaitu Persatuan Keluarga Besar Musthafawiyah Sibanggor Jae (KBMSJ).

Keluarga Besar Musthafawiyah Sibanggor Jae (KBMSJ) berdiri sejak tahun 1996. Pada awalya persatuan ini lahir dari persatuan induk yakni,Keluarga Besar Musthafawiyah Daerah Sibanggor (KBMDS). KBMDSmerupakan gabungan keluarga besar dari Sibanggor Jae, Tonga, Julu. Namun, semakin banyaknya anak Sibanggor Jae yang sekolah ke Musthafawiyah sehingga mereka membentuk persatuan sendiri yaitu keluarga besar Musthafawiyah Sibanggor Jae.

Persatuan Sibanggor Jae ini tertinggal dengan persatuan lainnya, karena apabila setiap ada acara pertandingan yang dilakukan di asrama antara persatuan-persatuan tidak pernah mendapatkan juara seperti persatuan lainnya, 
mereka mengikuti acara tersebut baik dalam lomba puisi, pidato, cerdas-cermat, tilawatil Quran, dan barzanji. Dalam hal ini persatuan ini hanya sekedar mengikutinya saja tidak berusaha untuk menampilkan yang terbaik.

Di dalam persatuan santri selalu dibina agar bisa mengembangkan keterampilan-keterampilan yang mereka miliki. Setiap hari Jum'at diadakan tablig untuk melatih kemampuan yang ada pada diri santri. Tablig dilakukan setiap satu kali seminggu untuk mengisi acara tersebut yaitu puisi, pidato, tilawatil Quran maka Ketua persatuan memberikan kesempatan untuk melatih dan menghafalnya sebelum ditampilkan minggu yang akan datang.

Dalam hal tersebut ketua persatuan hanya sekedar mengarahkanapabila yang ditampilkan anggotanya kurang bagus dari yang diharapkan ketua tidak memperbaikinya sehingga penampilan anggotanya tidakberlangsungdengan baik seperti yang diharapkan. Dalam hal ini tablig yang mereka lakukan hanya sekedar melepaskan kewajiban saja tidak peduli untuk bisa diaplikasikan dalam kehidupannya. Padahal guna tablig ini adalah untuk melatih mental sehingga apabila nanti sudah tamat dari Pesantren mereka sudah pandai bagaimana melakukan ceramah yang baik dan dari keterampilan dan kemampuan yang mereka miliki sehingga bisa mencari lapangan pekerjaan dari keterampilan yang telah dibina selama di Pesantren.

Dalam lembaga pendidikan tidaklah cukup hanya dengan membentuk budi pekerti saja, melainkan diperlukan berbagai pengetahuan dan keterampilan (skill). Di persatuan inilah mereka dituntut untuk bisa mengembangkan potensi yang ada pada diri mereka baik itu puisi, pidatoi, tilawatil Quran, dan barzanji. Di dalam persatuan diajarkan beberapa keterampilan sebagai bekal hidup mandiri. Akan tetapi mereka tidak menggunakan kesempatan ini sebagai pembelajaranuntuk bisa lebih bagus. Ketua persatuan juga kurang tegas dalam memimpin anggotanya sehingga persatuan ini tidak seperti yang diharapkan dalam mengembangkan keteraampilan yang ada pada diri anggotanya.

Dengan demikian, ketua persatuan harus berusaha sekuat mampu untuk mengajari anggotanya agar bisa menampilkan keterampilan yang ada pada diri anggotanya. Dalam hal ini perlu ada latihan dan binaan sehinga kemampuan dan keterampilan yang ada pada diri mereka dapat diterapkan dalam kehidupannya.

Berdasarkan latar belakang di atas, maka penulis tertarik untuk mengadakan penelitian dengan judul "Upaya Persatuan Pelajar Keluarga Besar Musthafawiyah Sibanggor Jae Dalam Meningkatkan Life Skill Santri di Pondok Pesantren Musthafawiyah Purba Baru". 


\section{Rumusan Masalah}

Dari uraian latar belakang masalah di atas, maka yang menjadi rumusan masalah dalam penelitian ini adalah:

a. Apa saja life skill santri yang ada di persatuan kelurga besar Musthafawiyah Sibanggor Jae?

b. Apa saja upaya yang dilakukan persatuan pelajar keluarga besar Musthafawiyah Sibanggor Jaedalam meningkatkan life skilkantri di Pondok Pesantren Musthafawiyah Purba Baru?

c. Apa kendala yang dihadapi persatuan pelajar keluarga besar Musthafawiyah Sibanggor Jae dalam menjalankan upaya meningkatakan life skillsantri di Pondok Pesantren Musthafawiyah Purba Baru?

\section{Pengertian Upaya}

\section{Tinjauan Teoritis}

Upaya, yaitu usaha, ikhtiar (untuk mencapai suatu tujuan yang dimaksud, memecahkan persoalan, mencari jalan keluar) yang dilakukan seseorang untuk mencapai tujuan yang diinginkan. ${ }^{2}$ Upaya yang dimaksud peneliti ini adalah usaha persatuan pelajar keluarga besar Musthafawiyah Sibanggor Jae dalam meningkatkan life skill santri di Pondok Pesantern Musthafawiyah Purba Baru.

\section{Pengertian Life Skill}

Life skill atau biasa disebut sebagai kecakapan hidup jika diruntut dari segi bahasa berasal dari dua kata yaitu life dan skill. Life berarti hidup, sedangkan skill adalah kecakapan, kepandaian, ketrampilan. Sehingga life skill secara bahasa dapat diartikan sebagai kecakapan, kepandaian atau ketrampilan hidup. Umumnya dalam penggunaan sehari-hari orang menyebut life skilldengan istilah kecakapan hidup. ${ }^{3}$

Dalam buku Guru Propesional Implementasi Kurikulum Tingkat Satuan Pendidikan disebutkan life skill adalahkecakapan yang dimiliki seseorang untuk beranai menghadapi problema hidup dan kehidupan dengan wajar tanpa merasa tertekan, kemudian secara proaktif dan kreatif mencari serta

${ }^{2}$ Tim Penyusun Kamus Pusat Bahasa, Kamus Besar Bahasa Indonesia (Jakarta: Balai Pustaka, 2005), hlm. 1250.

${ }^{3}$ Ahmad Wahyudin, Pengembangan Model Pembelajaran Life Skill,http/www Ahmadwahyudin, diakses 05 Mei 2015 Pukul 11.00 WIB. 
menemukan solusi sehingga mampu mengatasinya. ${ }^{4}$ Kemampuan tersebut diperlukan untuk menempuh kehidupan yang sukses, bermartabat, seperti kemampuan berpikir kompleks dan kritis, berkomunikasi secara efektif, membangun kerja sama, bertanggungjawab sehingga ada kesiapan untuk memasuki dunia kerja.Dalam buku Materi Pokok Pembelajaran Berwawasan Kemasyarakatan disebutkan Bloringlife skill adalah intraksi berbagai pengetahuan dan kecakapan yang sangat penting dimiliki oleh seseorang sehingga mereka dapat hidup mandiri. ${ }^{5}$

Berbeda dengan Anwar life skill adalah pendidikan yang dapat memberikan bekal keterampilan yang praktis, terpakai, terkait dengan kebutuhan pasar kerja, peluang usaha dan potensi ekonomi industri yang ada di masyarakat. Life skil ini memiliki cakupan yang luas, berintraksi antara pengetahuan yang diyakini sebagai unsur penting untuk hidup lebih mandiri. ${ }^{6}$

WHO mendefenisikan life skil adalah kemampuan untuk beradaptasi dan prilaku positif yang memungkinkan seseorang memenuhi kebutuhannya secara efektif dan menghadapi tantangan dalam kehidupan sehari-hari. Dengan demikian kecakapan hidup jangan dimaknai secara sempit dengan aksentuasi keterampilan fisik semata, tetapi juga bermakna sebagai sikap, prilaku, dan motivasi yang diperlukan untuk terampil menghadapi berbagai persoalan kehidupan. ${ }^{7}$ Life skill sangat erat kaitannya dengan berbagai persoalan dalam kehidupan bermasyarakat baik dalam masalah ekonomi, pasar kerja, dan peluang usaha. Sebagaimana tercantum dalam surat an-Nisa' ayat 9 yang berbunyi:

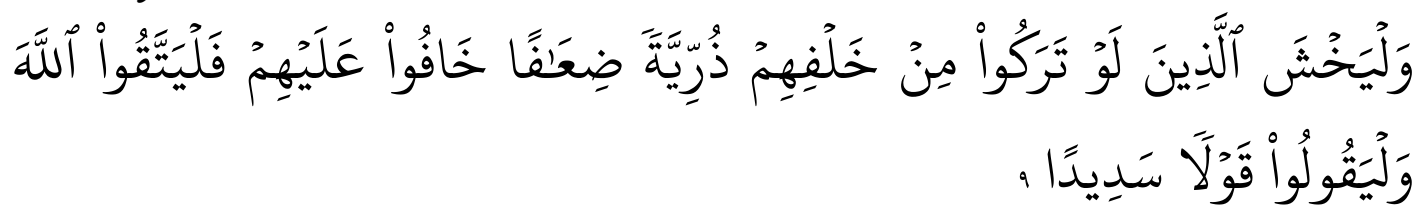

Artinya: Dan hendaklah takut (kepada Allah) orang-orang yang sekiranya mereka meninggalkan keturunan yang lemah di belakang mereka yang mereka khawatir terhadap (kesejahteraan) nya. Oleh sebab itu,

${ }^{4}$ Kunandar, Guru Profesional Implementasi Kurikulum Tingkat Satuan Pendidikan (KTSP) dan Sukses dalam Sertifikasi Guru (Jakarta: Rajawali Pers, 2009), hlm. 289.

5lihat Hatimah, Materi Pokok Pembelajaran Berwawasan Kemasyarakatan (Jakarta: Universitas Terbuka, 2008), hlm. 8.4.

${ }^{6}$ Anwar, Pendidikan Kecakapan Hidup (Life skils Education) (Bandung: Alfabeta, 2006), hlm. 20.

${ }^{7}$ Suryono, Haryianto, Belajar dan Pembelajaran (Bandung: Remaja Rosdakarya, 2012), hlm. 174. 
hendaklah mereka bertaqwa kepada Allah, dan hendaklah mereka berbicara dengan tutur kata yang benar. (An-Nisa/4:9)

Ayat ini memberi pesan kepada orang yang memelihara anak yatim orang lain agar memiliki kekhawatiran kalau-kalau di kemudian hari mereka terlantar dan tak berdaya, sebagaimana ia khawatir kalau hal itu terjadi pada anak-anak kandung mereka sendiri. Ketidak berdayaan itu tidak melulu menyangkut soal ekonomi semata, tetapi pada seluruh aspek kehidupan. Setiap orang dewasa bertanggungjawab terhadap perkembangan masa depan generasi mudanya, jangan sampai mereka termarginalisasi karena tidak memiliki pengetahuan, kemampuan, keterampilan, kesempatan, dan semua hal yang diperlukan untuk maju dan berkembang secara sehat dan bermartabat serta diridhai Allah swt.

Secara umum diakui bahwa salah satu tugas setiap orangtua, masyarakat, dan pemerintah adalah mempersiapkan ganerasi yang tangguh dalam aspek kehidupan. Cara terbaik untuk melakukan hal tersebut adalah melalui pendidikan yang bermutu yang dapat menggali dan mengembangkan semua potensi yang dimiliki secara optimum. Betapa banyak potensi manusia yang tidak teraktualisasikan dengan sempurna. Boleh jadi di sekililing kita terdapat banyak orang (peserta didik) yang berada pada posisi under achiever, berprestasi jauh di bawah potensi sebenarnya.

Dari beberapa pengertian di atas dapat disimpulkan bahwa life skill adalah merupakan kecakapan-kecakapan yang secara praktis dapat membekali peserta didik dalam mengatasi berbagai macam persoalan hidup dan kehidupan. Kecakapan itu menyangkut aspek pengetahuan, sikap yang di dalamnya termasuk fisik dan mental serta kecakapan kejuruan yang berkaitan dengan pengembangan akhlak sehingga mampu menghadapi tuntutan dan tantangan hidup dalam kehidupan. Jadi seseorang dikatakan memiliki life skill apabila yang bersangkutan mampu, sanggup, dan terampil menjalankan kehidupan dengan nikmat dan bahagia.Dengan bekallife skillyang baik, diharapkan para lulusan akan mampu memecahkan problema kehidupan yang dihadapi, termasuk mencari atau menciptakan lapangan pekerjaan bagi mereka yang tidak melanjutkan pendidikannya. 


\section{Konsep Life Skill}

Departemen pendidikan Nasional membagi life skill menjadi empat jenis, yaitu: ${ }^{8}$

a. Kecakapan personal (Personal skill)

Kecakapan personal yang mencakup kecakapan mengenal diri (self awarense) dan kecakapan berfikir rasional (sosial skill). Kecakapan mengenal diri pada dasarnya merupakan penghayatan diri sebagai mahkluk Tuhan Yang Maha Esa, anggota masyarakat dan warga negara, serta menyadari dan mensyukuri kelebihan dan kekurangan yang dimiliki sebagai modal dalam meningkatkan dirinya sebagai indifidu yang bermanfaat bagi dirinya sendiri maupun lingkungannya. Kecakapan berfikir rasional mencakup antara lain: kecakapan menggali dan menemukan informasi, kecakapan mengolah informasi dan mengambil keputusan, kecekapan memecahkan masalah serta secara kreatif.

b. Kecakapan Sosial (social skill)

Kecakapan sosial mencakup antara lain kecakapan komunikasi dan empati, dan kecakapan bekerja sama. Empati sikap penuh pengertian dan seni komunikasi dua arah, perlu ditekankan karena yang dimaksud berkomunikasi di sini bukan sekedar menyampaikan pesan, tetapi isi dan sampainya pesan disertai dengan kesan yang baik menumbuhkan hubungan harmonis. ${ }^{9}$

c. Kecakapan Akademik (accademic skill)

Kecakapan akademik yang sering kali juga disebut kemampuan berfikir ilmiah pada dasarnya merupakan pengembangan dari kecakapan berfikir rasional bersifat umum.Jika berfikir rasional bersifat umum, kecakapan akademik lebih menjurus kepada kegiatan yang bersifat akademik/keilmuan. Kecakapan akademik mencakup anatara lain kecakapan melakukan identifikasi variabel dan menjelaskan hubungannya pada suatu fenomena tertentu, merumuskan hipotesis terhadap suatu rangkaian kejadian, serta merancang dan melaksanakan penelitian untuk membuktikan suatu gagasan atau keingintahuan.

d. Kecakapan Vokasional

Kecakapan vokasional sering kali disebut dengan kecakapan kejuruan, artinya kecakapan yang dikaitkan dengan bidang pekerjaan tertentu yang terdapat di masyarakat. Perlu disadari bahwa di alam kehidupan nyata, antara generallife skill dan specific life skill yaitu antara kecakapan mengenal diri, kecakapan

\footnotetext{
${ }^{8}$ Anwar, Op.Cit., hlm. 28.

${ }^{9}$ Ibid., hlm. 29.
} 
berfikir rasional, kecakapan sosial dan kecakapan akademik serta kecakapan vokasional tidak berfungsi secara terpisah-pisah, atau tidak terpisah secara eksklusif. Hal yang terjadi adalah peleburan kecakapan-kecakapan tersebut, sehinggga menyatu menjadi sebuah tindakan individu yang melibatkan asfek fisik, mental, emosional, dan intelektual.

\section{Tujuan dan Manfaat Life Skill}

a. Tujuan life skill

Esensi dari pendidikan life skill adalah untuk meningkatkan relevansi pendidikan dengan nilai-nilai kehidupan nyata, baik preservatif maupun progresif. Lebih sfisikasinya tujuan pendidikan life skill dapat dikemukan sebagai berikut:

1) Memberdayakan aset kualitas batiniah, sikap, dan perbuatan lahiriah peserta didik melalui pengenalan (logos), penghayatan (etos), dan pengalaman (patos) nilai kehidupan sehari-hari sehingga dapat digunakan untuk menjaga kelangsungan hidup dan perkembangannya.

2) Memberikan wawasan yang luas tentang pengembangan karir, yang dimulai dari pengenalan diri, ekspolorasi karir, orientasi karir, dan menyiapkan karir.

3) Memberikan bekal dasar dan latihan-latihan yang dilakukan secara benar mengenai nilai-nilai kehidupan sehari-hari yang dapat memampukan peserta didik untuk berfungsi menghadapi kehidupan masa depan yang syarat kompetensi dan kolaborasi sekaligus.

4) Mengoptimalkan pemampatan sumber daya sekolah melalui pendekatan manajemen berbasis sekolah dengan mendorong peningkatan kemandirian sekolah, partisipasi pengambil kebijakan dan fleksibilitas pengelolaan sumber daya sekolah.

5) Mempasilitasi peserta didik dalam memecahkan permasalahan kehidupan yang dihadapi sehari-hari seperti kesehatah mental dan fisik, kemiskinan, kriminal, pengangguran, narkoba, dan kemajuan iftek. ${ }^{10}$

b. Manfaat life skill

Manfaat dari pendidikan kecakapan hidup (life skill) adalah sebagai berikut:

1) Memfungsikan pendidikan sesuai fitrahnya, yaitu mengembangkan potensi manusiawi peserta didik menghadapi perannya di masa yang akan datang.

${ }^{10} \mathrm{Ibid} .$, hlm. 43. 
2) Memberikan peluang bagi intitusi pelaksana dan memanfaatkan potensi sumber daya yang ada di masyarakat sesuai dengan prinsip pendidikan terbuka (berbasis luas dan mendasar) serta prinsip manajemen pendidikan berbasis sekolah.

3) Membekali tamatan dengan kecakapan hidup agar kelak mampu menghadapi dan memecahkan permasalahan hidup dan kehidupan, baik sebagai pribadi yang mandiri, masyarakat, dan warga Negara. ${ }^{11}$

Meskipun sangat bervariasi dalam menyatakan tujuan pendidikan kecakapan hidup, namun dari pernyataan tersebut, konvergensinya sudah begitu jelas bahwa tujuan utama pendidikan kecakapan hidup adalah menyiapkan yang bersangkutan mampu, sanggup, dan terampil menjaga kelangsungan hidup dan perkembangannya di masa akan datang, serta esensi dari pendidikan kecakapan hidup adalah untuk meningkatkan relevansi pendidikan dengan nilai-nilai kehidupan nyata, baik preservatif maupun progresif. Sedangkan Manfaat pendidikan kecakapan hidup Secara umum pendidikan berorientasi kecakapan hidup adalah sebagai bekal dalam menghadapi dan memecahkan problem hidup dan kehidupan, baik sebagai pribadi yang mandiri, warga masyrakat, maupun sebagai sebagai warga Negara.

\section{Upaya dalam Meningkatkan Life Skill}

Ada beberapa upaya dalam meningkatkan life skill antara lain:

a. Disiplin

Disiplin merupakan masalah penting. Tanpa adanya kesadaran akan memetuhi aturan yang sedang ditentukan. Kedisiplinan erat kaitannya dengan pemanfaatan waktu secara efektif, hal ini sejalan dengan firman Allah dalam surat al-'Asr ayat 1-3, yang berbunyi:

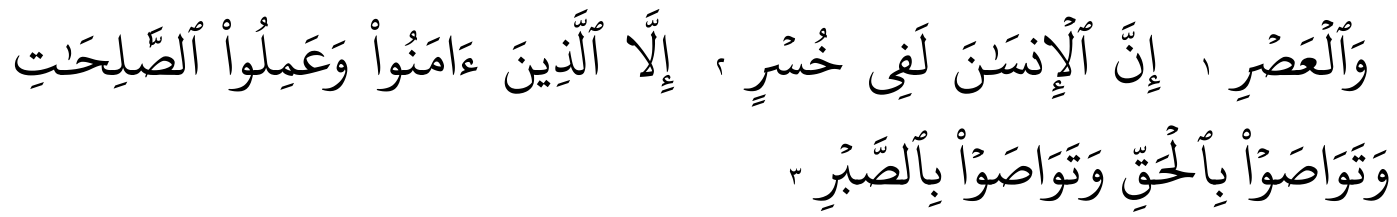

Artinya: Demi masa. Sesungguhnya manusia itu benar-benar dalam kerugian, Kecuali orang-orang yang beriman dan mengerjakan amal saleh dan nasehat menasehati supaya mentaati kebenaran dan nasehat menasehati supaya menetapi kesabaran. ${ }^{12}$

\footnotetext{
${ }^{11}$ Kunandar, Op.Cit., hlm. 290.

12 Departemen Agama RI, Mushaf Alquran dan Terjemahan (Jakarta: Pustaka Al-Kautsar, 2009), hlm. 601.
} 
b. Motivasi

Motivasi (motivation) adalah rangsangan, dorongan, atau pembangkit tenaga bagi terjadinya suatu tingkah laku. ${ }^{13}$ Motivasi adalah dorongan untuk berbuat sesuatu (drive) di dalam memenuhi kebutuhan. ${ }^{14}$ Dalam hal ini motivasi adalah yang mendorong seseorang untuk melakukan sesuatu. Motivasi terbagi dua yaitu:

1) Motivasi intrinsik adalah motivasi yang datang dari dalam diri seseorang, contoh anggota melakukan suatu kegiatan karena ingin menguasai suatu keterampilan tertentu yang dipandang akan berguna dalam pekerjaannya.

2) Motivasi ekstrinsik adalah motivasi yang berasal dari lingkungan di luar diri seseorang, contoh anggota bekerja karena ingin mendapat pujian atau ingin mendapat hadiah dari pemimpinnya. ${ }^{15}$

Keberhasilan suatu organisasi atau lembaga dipengaruhi oleh berbagai faktor, baik faktor yang datang dari dalam maupun yang datang dari lingkungan. Setiap anggota memiliki karakteristik khusus, yang satu sama lain berbeda. Hal tersebut memerlukan perhatian dan pelayanan khusus pula dari pemimpinnya, agar mereka dapat untuk meningkatkan kinerjanya. Perbedaan anggota tidak hanya dalam bentuk fisik, tetapi juga dalam fisikisnya, misalnya motivasi. Oleh kerena itu untuk meningkatkan kinerja, perlu diupayakan untuk membangkitkan motivasi para anggota dan faktorfaktor lain yang mempengaruhinya.

c. Latihan

Latihan adalah suatu pengaruh yang dilakukan seorang pemimpin untuk memberi pengaruh kepada anggotanya untuk meningkatkan kecakapan guna suatau meningkatkan suatu kegiatan tertentu. Latihan ini adalah lebih banyak pada aspek keterampilan dari pada sekedar pendidikan/pengajaran yang berhubungan dengan memberikan, karena latihan mencakup baik pengalaman mengerjakan suatu pekerjaan maupun pengetahuan. Latihan bertujuan untuk membangun dan mengembangkan pengetahuan dan keterampilan yang dimiliki guna untuk mencapai tujuan yang diinginkan. Hidayat dan Syamsulbahri yang dikutip oleh Anwar, mengatakan ada tiga hal yang perlu diperhatikan dalam penyusunan perogram latihan yang akan dilaksanakan yaitu: 1) bahan belajar latihan, 2) metode/teknik, 3) evaluasi

\footnotetext{
${ }^{13}$ Ahmad Fauzi, Psikologi Umum (Bandung: Pustaka Setia, 2008), hlm. 58.

${ }^{14}$ Syafaruddin, Kepemimpinan dan Kewirausahaan (Medan, Perdana Publishing, 2010),
} hlm. 122.

${ }^{15}$ E. Mulyasa, Op.Cit., hlm. 120. 
latihan. Asumsi dasar yang diterapkan dalam ha ini adalah materi dan metode/teknik latihan harus disesuaikan dengan karakteristik dari binaan dan kebutuhan rill untuk meningkatkan usaha yang telah dikembangkan. ${ }^{16}$

\section{Sejarah Berdirinya Persatuan Keluarga Besar Musthafawiyah Sibanggor Jae}

Persatuan keluarga besar Musthafawiyah Sibanggor Jae didirikan pada tanggal 09 April 1996. Pada awalnya persatuan ini lahir dari persatuan induk yaitu persatuan keluarga besar Musthafawiyah Daerah Sibanggor (KBMDS) merupakan gabungan keluarga besar dari Sibanggor Jae, Tonga, Julu. Dengan banyaknya anak Sibanggor Jae yang sekolah ke Musthafawiyah sehingga persatuan ini keluar dari persatuan induk tersebut dan persatuan ini membentuk persatuan sendiri yaitu Persatuan Keluarga Besar Musthafawiyah Sibanggor Jae. Setelah terbentuknya persatuan keluarga besar Musthafawiyah Sibanggor Jae ini maka yang menjadi ketua persatuan pada masa itu yang bernama Abdul Manan. Kemudian persatuan ini terbentuklah sampai sekarang dan pemilihan ketua persatuan dilakukan setap satu kali dalam setahun. ${ }^{17}$ Seperti organisasi lainnya, persatuan keluarga besar Musthafawiyah Sibanggor Jae memiliki visi dan misi sebagai pedoman dalam melaksanakan berbagai kegiatan.

Keluarga besar Musthafawiyah Sibanggor Jae dibentuk di samping untuk mempererat hubungan silaturrahmi antara anggota persatuan juga untuk mempertinggi mutu pendidikan sebagai dimaksudkan dalam Anggaran Dasar dan Anggaran Rumah Tangga keluarga besar Musthafawiyah Sibanggor Jae. Berikut gambaran Anggaran Dasar dan Anggaran Rumah Tangga dan Visi Misi Persatuan keluarga besar Musthafawiyah Sibanggor Jae.

\section{a. Anggaran Dasar}

Pasal I Asal Kepengurusan

Ayat I : Pengurus KBMSJ terdiri dari Ketua/wakul ketua, Sekretaris/wakil sekretaris, Bendahara/wakil bendahara, Humas.

Ayat II : Pengurus yang tidak menjalankan tugasnya dengan baik para anggota wajib menuntutnya.

Ayat III : Pengurus KBMSJ diganti dan dibubarkan sebanyak satu kali dalam setahun yang dipilih seluruh anggota dengan jalan musyawarah dan suara terbanyak.

Pasal II Keanggotaan

Anggota KBMSJ terdiri dari daerah Sibanggor Jae

\footnotetext{
${ }^{16}$ Anwar, Op.Cit., hlm. 163-164.

${ }^{17}$ Abdul Manan, Ketua Persatuan Pertama, Wawancara, Tanggal 17 Januari 2015.
} 
Pasal III Tujuan dan Maksud

Ayat I : Adanya persatuan KBMSJ untuk mempertinggi mutu pendidikan anggota persatuan, mempererat rasa persatuan dan kesatuan serta kekeluargaan.

Ayat II : Apabila ada anggota persatuan KBMSJ mendapat musibah maka persatuan KBMSJ wajib membantu atas dasar kesadaran dan keikhlasan.

b. Anggaran Rumah Tangga

Pasal I Kegiatan Ekstrakulikuler

1. Setiap warga KBMSJ apabila tidak masuk satu kali/2 kali dalam pertablikan dan pertahtiman tanpa alasan atau alasan yang tidak tertentu diberikan nasehat oleh pengurus KBMSJ.

2. Setiap anggota yang ditunjuk orator/pidato tidak boleh melihat buku.

3. Siapa-siapa yang memancing keributan sewaktu takhtim, tablig dan kursus stap-stap persatuan wajib bertindak.

4. Setiap anggota KBMSJ wajib ikut taraweh, tadarus bagi anggota yang tidak hadir akan diberi sangsi.

5. Apabila ada yang terkena musibah anggota, maka segera dilaporkan kepada ketua/wakil persatuan KBMSJ Putri.

6. Takhtim setiap malam Minggu bagi yang tidak hadir (A) akan diberi sangsi dan diwajibkan bagi kelas 1, 2 dan 3 membawa takhtim dan wajib memakai telekung dan tidak boleh memakai tangan pendek.

7. Bagi anggota persatuan yang terlambat memasuki ruangan tablig akan diberi sanksi berdiri selama berapa menit terlambat.

8. Apabila anggota persatuan tidak hadir dalam pertablikan akan diberi sanksi berdiri selama waktu tablig dan didenda Rp 3000.

9. Di wajibkan bagi kelas 1, 2, dan 3 kursus pagi dari hari Rabu-Senin mulai jam 06.30-07.15.

10. Setiap malam Selasa kumpul dan membawa buku pelajaran yang ditentukan bagi yang tidak datang akan diberi sangsi.

11. Bagi seluruh anggota wajib hadir di tempat perayaan kecuali dengan alasan tertentu dan tepat.

12. Setiap warga KBMSJ wajib membayar osis setiap Minggu.

13. Setiap anggota yang melanggar undang-undang dinasehati oleh stap-stap persatuan dan kelas VII, apabila perbuatannya masih terulang di serahkan kepada stap-stap persatuan pokir dan sampai terulang tiga kali dikeluarkan dari persatuan KBMSJ. 
14. Bagi stap-stap yang tidak menjalankan tugasnya dengan baik para anggota berhak bertindak.

15. Pengurus KBMSJ dibubarkan satu kali dalam satu tahun yang dipilih seluruh anggota dengan jalan musyawarah dan suara terbanyak.

16. Undang-undang ini berlaku selama masih ikut persatuan KBMSJ.

17. Bagi siapa-siapa yang tidak sanggup mematuhi undang-undang KBMSJ diperbolehkan keluar dari persatuan.

c. Visi

Terciptanya anggota persatuan yang berkualitas, terampil serta bisa menjadi tauladan dalam masyarakat.

d. Misi

1. Melaksanakan pembelajaran dan bimbingan secara efektif sehingga setiap potensi anggota persatuan berkembang secara optimal.

2. Mendorong dan membantu anggota persatuan untuk mengenali potensi dirinya sehingga dapat berkembang secara optimal ${ }^{18}$

\section{Metodologi Penelitian}

\section{Lokasi dan Waktu Penelitian}

Yang menjadi subjek penelitian ini adalah persatuan pelajar keluarga besar Musthafawiyah Sibanggor Jae, persatuan ini berdiri sejak tahun 1996. Pada awalnya persatuan ini lahir dari persatuan induk yakni, Keluarga Besar Musthafawiyah Daerah Sibanggor (KBMDS) merupakan gabungan keluarga besardari Sibanggor Jae, Tonga, Julu. Penelitian ini berlokasi di Pondok Pesantren Musthafawuyah Purba Baru Kecamatan Lembah Sorik Marapi Kabupaten Mandailing Natal.

\section{Jenis Penelitian}

Penelitian ini termasuk penelitian kualitatif yang bersifat eksploratif yaitu penelitian yang dilakukan dengan tujuan untuk mengungkapkan suatu fenomena tertentu dan hal-hal yang berhubungan dengan fenomena tersebut seperti apa adanya. ${ }^{19}$ Jadi penelitian ini dilakukan dengan tujuan untuk mendapatkan gambaran tentang Upaya Persatuan Pelajar Keluarga Besar

${ }^{18}$ Idris, N. dkk. 1987. Pemanfaatan Media untuk Kegiatan Interaktif dalam PJJ bagi Para Guru yang Belajar di UT. Kumpulan Makalah Seminar Nasional Pemanfaatan Jaringan Komunikasi Pendidikan. 9 - 10 September 1987.

${ }^{19}$ Sukarsi, Metodologi Penelitian Kompetensi dan Praktik (Jakarta: Bumi Aksar, 2008), hlm. 7. 
Musthafawiyah Sibanggor Jae Dalam Meningkatkan Life Skill Santri di Pondok Pesantren Musthafawiyah Purba Baru.

\section{Informan Penelitian}

Yang menjadi informan dalam penelitian ini adalah seluruh struktur organisasi persatuan pelajar keluarga besar Musthafawiyah Sibanggor Jae, yang berjumlah 12 orang. Artinya informan dalam penelitian ini sebanyak 12 orang. Jumlah keseluruhan anggota persatuan keluarga besar Musthafawiyah Sibanggor Jae adalah 51 orang.

\section{Sumber dan Data Penelitian}

Sumber data dalam penelitian ini ada dua jenis yang dibutuhkan yaitu sumber data primer dan sumber data sekunder. ${ }^{20}$

a. Sumber data primer, data primer adalah data pokok dalam penelitian. Data pokok yang dibutuhkan dalam penelitian ini adalah dariseluruh struktur organisasipersatuan pelajar keluarga besar Musthafawiyah Sibanggor Jae.

b. Sumber data skunder, data sekunder adalah sumber data pelengkap atau pendukung untuk menguatkan data primer. ${ }^{21}$ Dalam hal ini adalah anggota persatuan keluarga besar Musthafawiyah Sibanggor Jae, guru pembimbing, dan bapak sekretaris Pondok Pesantren Musthafawiyah Purba Baru.

\section{Teknik Pengumpulan data}

Dalam pengumpulan data, sangat diperlukan dalam penelitian. Dengan alat yang baik penelitian ini lebih mudah mendapatkan data yang lebih valid. Adapun instrumen pengumpulan data dalam penelitian ini adalah.

a. Observasi

Observasi dalam penelitian ini langsung dilakukan peneliti ke lokasi penelitian, yaitu di Pondok Pesantren Musthafawiyah Purba Baru. Kegiatan yang diobservasi adalah kegiatan yang berkaitan dengan upaya peningkatkan life skill santri di Pondok Pesantren Musthafawiyah Purba Baru.

b. Wawancara

Bentuk wawancara terbagi kepada dua, yaitu terstruktur dan tidak terstruktur. Wawancara terstruktur adalah suatu bentuk wawancara dimana pewawancara dalam hal ini menyusun pedoman wawancara secara terstruktur menurut format yang baku. Sedangkan wawancara tidak terstruktur adalah pedoman wawancara yang disusun peneliti, tetapi tidak

\footnotetext{
${ }^{20}$ Saiful azwar, Metode Penelitian (Yogyakarta: Pustaka pelajar, 2004), hlm. 91.

${ }^{21}$ Sugiyono, Metode Penelitian Kuantitatif dan R\&D (Bandung: Alpabeta, 2008), hlm. 400.
} 
menggunakan format dan urutan yang baku. Adapun bentuk wawancara yang peneliti gunakan adalah wawancara terstruktur mendalam.

\section{Teknik Pengolahan dan Analisis Data}

Menurut Nana Syaodih Sukmadinata teknik pengolahan data dapat dilakukan sebagai berikut: 1) Menelaah seluruh data yang didapat di lapangan dan kemudian melihat data mana yang harus ditulis dan data mana yang tidak dituliskan, 2) Mengadakan reduksi adalah menganalisis data secara keseluruhan kepada data yang lebih sederhana, 3) Menyusun data secara yang berkenaan dengan persepsi orangtua terhadap pendidikan anak, 4) Data-data dikelompokkelompokkan sesuai dengan yang dibutuhkan, 5) Kemudian mengadakan pemeriksaan kembalai terhadap data-data yang didapatkan di lapangan, apakah sudah layak disajikan menjadai tulisan. ${ }^{22}$

\section{Teknik Keabsahan Data}

Keabsahan data merupakan konsep yang sangat penting dalam sebuah penelitian, karena pemeriksaan terhadap keabsahan data ini digunakan untuk menyanggah tuduhan kepada penelitian kualitatif yang mengatakan tidak ilmiah. Agar hasil penelitian kualitatif memiliki tingkat kepercayaan yang tinggi sesuai dengan fakta di lapangan diperlukan upaya-upya. Pemeriksaan keabsahan data yang digunakan dalam penelitian ini berdasarkan teknik yang dikemukakan oleh Maleong, yaitu:

a. Memperpanjang keikutsertaan peneliti dalam proses pengumpulan data di lapangan. Hal ini dilakukan karena dalam penelitian kualitatif, peneliti merupakan instrumen utama dalam penelitian. Semakin lamanya peneliti terlibat dalam pengumpulan data, maka kepercayaan terhadap data yang dikumpulkan semakin meningkat.

b. Melakukan observasi secara terus menerus dan sungguh-sunguh sehingga peneliti semakin mendalami fenomena sosial yang diteliti seperti apa adanya. Teknik observasi boleh dikatakan merupakan keharusan dalam pelaksanaan penelitian kualitatif. Hal ini disebabkan banyaknya penomena sosial yang sulit terungkap bila hanya digali melalui wawancara. ${ }^{23}$

\footnotetext{
${ }^{22}$ Nana Syaodih Sukmadinata, Metode penelitian Pendidikan (Bandung: Remaja Rosdakarya, 2012), hlm. 155.

${ }^{23}$ Lexy J. Moleong, Op.Cit., hlm. 90.
} 


\section{Hasil dan Pembahasan}

\section{Temuan Umum}

Persatuan keluarga besar Musthafawiyah Sibanggor Jae berdiri pada tanggal 09 April 1996. Pada awalnya persatuan ini lahir dari persatuan induk yaitu persatuan keluarga besar Musthafawiyah Daerah Sibanggor (KBMDS) merupakan gabungan keluarga besar Musthafawiyah dari Sibanggor Jae, Tonga, dan Julu. Dengan banyaknya anak Sibanggor Jae yang sekolah ke Musthafawiyah, persatuan ini keluar dari persatuan induk tersebut dan membentuk persatuan sendiri,dengan nama Persatuan Keluarga Besar Musthafawiyah Sibanggor Jae (KBMSJ). ${ }^{24}$

Persatuan keluarga besar Musthafawiyah Sibanggor Jae ada dua. Pertama IPMSJ (Ikatan Pelajar Musthafawiyah Sibanggor Jae) persatuan ini mewadahi kegiatan-kagitan yang dilakukan oleh santri yang dilaksanakan di Desa Sibanggor Jae. Kedua persatuan KBMSJ (keluarga besar Musthafawiyah Sibanggor Jae), mewadahi kegiatan-kegiatan yang dilakukan oleh santriyati Musthafawiyah. Artinya persatuan ini hanya terdiri dari santri perempuan yang dilaksanakan di pondok pesantren Musthafawiyah. Dalam hal ini yang menjadi pokus penelitian adalah persatuan keluarga besar Musthafawiyah Sibanggor Jae yang dilaksanakan di lokasi pondok pesantren Musthafawiyah Purba Baru.

Secara organisator persatuan ini memiliki struktur organisasi yang terdiri dari ketua persatuan/wakil ketua, bendahar/wakil bendahara, sekretaris/wakil sekretaris dan humas/wakil humas dan penasehat, Berikut denahnya. ${ }^{25}$

${ }^{24}$ Abdul Manan, Ketua Persatuan KBMSJ Pertama, Wawancara, Tanggal 17 Januari 2015.

${ }^{25}$ Dokumen Persatuan Pelajar KBMSJ, Tanggal 02 Agustus 2015. 


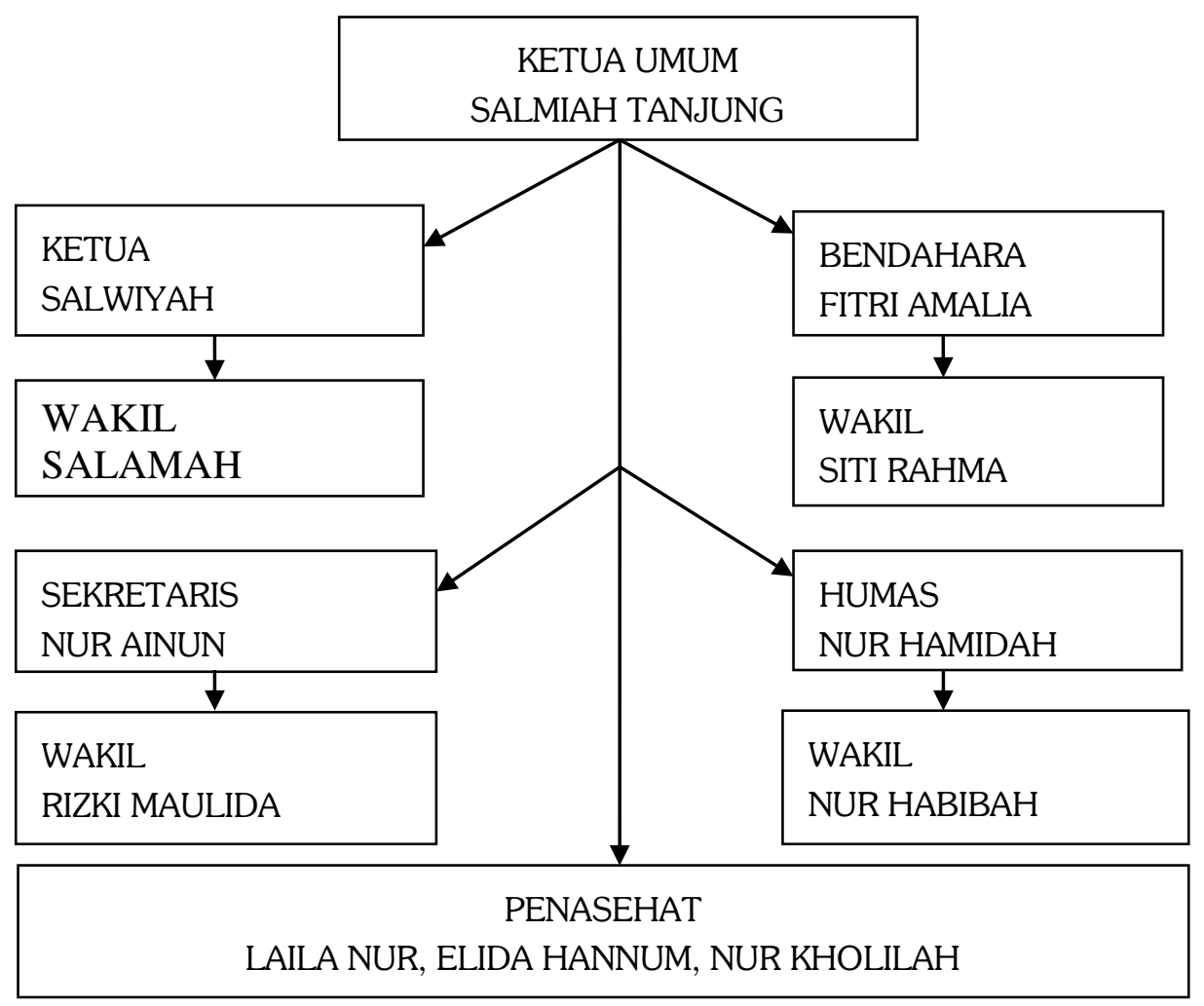

Dalam upaya mengembangkan life skill para anggota keluarga besar Musthafawiyah Sibanggor Jae, ada beberapa kegiatan yang dilakukan. Berikutbentuk tabel kegiatannya.

\begin{tabular}{|l|l|l|c|l|}
\hline No & \multicolumn{1}{|c|}{ Kegiatan } & \multicolumn{1}{|c|}{ Hari } & \multicolumn{1}{|c|}{ Waktu } & \multicolumn{1}{|c|}{ Yang membidangi } \\
\hline 1 & Puisi & Senin & $06.30-07.15$ & $\begin{array}{l}\text { Laila Nur, Nur Hamidah, } \\
\text { Nur Habibah }\end{array}$ \\
\hline 2 & Pidato & Rabu & $06.30-07.15$ & $\begin{array}{l}\text { Salmiah, Nur Ainun, Nur } \\
\text { Kholilah }\end{array}$ \\
\hline 3 & Tilawatil Quran & Sabtu & $06.30-07.15$ & $\begin{array}{l}\text { Fitri Maliah, Salwiyah, } \\
\text { Elida Hannum }\end{array}$ \\
\hline 4 & Barzanji & Kamis & $06.30-07.15$ & $\begin{array}{l}\text { Siti Rahma, Rizki Maulida, } \\
\text { Salamah }\end{array}$ \\
\hline
\end{tabular}

Persatuan keluarga besar Musthafawiyah Sibanggor Jae beranggotakan 51 orang dengan kelas yang berbeda-beda. Berikut tabelnya. ${ }^{26}$

${ }^{26}$ Dokumen Persatuan Pelajar KBMSJ, Tanggal 02 Agustus 2015. 


\begin{tabular}{|l|l|l|}
\hline No & Kelas & Jumlah \\
\hline 1 & 7 (Tujuh) & 7 Orang \\
\hline 2 & 6 (Enam) & 5 Orang \\
\hline 3 & 5 (Lima) & 7 Orang \\
\hline 4 & 4 (Empat) & 7 Orang \\
\hline 5 & 3 (Tuga) & 6 Orang \\
\hline 6 & 2 (Dua) & 5 Orang \\
\hline 7 & 1 (Satu) & 14 Orang \\
\hline \multicolumn{2}{|l|}{ Jumlah keseluruhan } & 51 Orang \\
\hline
\end{tabular}

\section{Temuan Khusus}

a. Life Skill Yang Ada di Persatuan Keluarga Besar Musthafawiyah Sibanggor Jae

Dalam hal ini life skill yang dibentuk dalam persatuan keluarga besar Musthafawiyah Sibanggor Jae adalahlife skill yang bersifat khusus yaitu kecakapan akademik dan vocasional. Kecakapan akademik adalah merupakan kemempuan berfikir secara ilmiah, vocasional adalah kecakapan yang terkait keterampilan melakukan suatu pekerjaan yang ingin ditekuni. Dalam hal ini di tubuh persatuan keluarga besar Musthafawiyah Sibanggor Jae yang mereka bentuk adalah kecakapan vocasional yang menyangkut keterampilan yang ingin ditekuni.

Di Pondok Pesantren Musthafawiyah ada kegiatan ektrakulikuler, khusus dilaksanakan oleh setiap organisasi. Masing-masing organisasi membina para santri dalam berbagai keterampilan dan bakat yang dimiliki para santri.Dalam organisasi staf persatuan berperan penting dalam mengembangkan bakat yang ada pada diri santri, dengan harapan keterampilan tersebut dapat menjadi bekal bagi santri sehingga mereka dapat mengaplikasikannya dalam kehidupan setelah tamat dari pesantren.

Berdasarkan hasil observasi peneliti melihat bahwa life skill yang ada dalam persatuan keluarga besar musthafawiyah Sibanggor Jae ada beberapa kegiatan yaitu puisi, pidato, tilawatil qur'an, barzanji dan Qasidah. ${ }^{27}$ Wawancara denganLaila Nur, ia mengatakan life skill yang ada di tubuh persatuan pelajar keluarga besar Musthafawiyah Sibanggor Jae ada empat kegiatan yaitu puisi, pidato, tilawatil Quran dan barzanji, keempat kegiatan ini merupakan kegiatan

\footnotetext{
${ }^{27}$ Observasi, Tanggal 11 Desember 2015 di Persatuan KBMSJ Pondok Pesantren Musthafawiyah Purba Baru.
} 
ekstrakulikuler yang dilaksanakan dengan tujuan untuk menberi bekal hidup bermasyarakat, menambah wawasan serta memberi kesempatan bagi santri untuk mengembangkan bakat dan keterampilan masing-masing. Dengan adanya kegiatan dalam suatu organisasi ini, diharapkan santri akan terdorong untuk mengembangkan bakat dan keterampilannya. ${ }^{28}$

b. Upaya yang Dilakukan Persatuan Pelajar Keluarga Besar Musthafawiyah Sibanggor Jae dalam Meningkatkan Life Skill Santri di Pondok Pesantren Musthafawiyah Purba Baru

Ada beberapa upaya yang dilakukan persatuan keluarga besar Musthafawiyah Sibanggor Jae dalam meningkatkan dan mengembangkan life skill. Upaya-upaya dimaksud adalah:

1) Disiplin

Berdasarkan observasi dan wawancara dengan santri dan staf persatuan di Pondok Pesantren Musthafawiyah, peneliti melihat bahwa disiplin santri berjalan dengan baik, hal ini dapat dilihat dari ketepatan waktu para anggota dan juga dari absensi atau kehadiran para anggota dalam meningkatkan kegiatan-kegiatan. ${ }^{29}$ Salmiah (Ketua umum persatuan) ia mengatakan, disiplin merupakan hal yang sangat penting dalam berbagai aktifitas manusia dan salah satu unsur dalam mencapai tujuan. Disiplin sangat erat kaitannya dengan kesadaran dan niat ikhlas dari hati nurani seseorang, karena ini berkaitan dengan kesediaan untuk mematuhi atau mengikuti peraturan. ${ }^{30}$ Pendapat yang sama denga Laila Nur mengatakan, disiplin santri seharusnya diawali dengan kesadaran dan niat yang ikhlas dari hati. Hal ini dikarenakan betapa besarnya manfaat dari disiplin dalam berbagai kehidupan dan juga dalam pelaksanaanya. $^{31}$

Berdasarkan wawancara dengan Nur Ainun, ia mengatakan disiplin santri dalam melaksanakan peraturan tentang kedisiplinan sudah berjalan dengan ketentuan yang ditetapkan, akan tetapi sabagian santri masih ada yang

${ }^{28}$ Laila Nur, Penasehat Persatuan KBMSJ, Wawancara, di Persatuan KBMSJ Pondok Pesantren Musthafawiyah Purba Baru, Tanggal 12 Desember 2015.

${ }^{29}$ Observasi, Tanggal 07 Agustus 2015 di Persatuan KMBSJ Pondok Pesantren Musthafawiyah Purba Baru.

${ }^{30}$ Salmiah, Ketua Umum Persatuan KBMSJ, di Persatuan KBMSJ Pondok Pesantren Musthafawiyah Purba Baru, Wawancara, Tanggal 07 Agustus 2015.

${ }^{31}$ Laila Nur, Penasehat Persatuan KBMSJ, Wawancara,di Persatuan KBMSJ Pondok Pesantren Musthafawiyah Purba Baru, Tanggal 07 Agustus 2015. 
terlambat dalam memasuki ruangan tablig. ${ }^{32}$ Wawancara dengan Elida Hannum, mengatakan dalam mensukseskan suatu kegiatan perlu adanya kesadaran dan keinginan yang kuat dari dalam diri seseorang, agar pelaksanaannya tidak menjadi kendala bagi aktivitas yang lain melainkan menjadi motivasi. ${ }^{33}$ Disiplin santri dalam memasuki ruangan tablig sangat mempengaruhi kelancaran dalam menjalankan kegiatan dalam upayauntuk meningkatkan life skill santri.

2) Latihan

Berdasarkan observasi peneliti melihat bahwa staf persatuan sedaya mampu mereka melatih anggotanya dalam berbagai bidang yang telah ditetapkan dalam persatuan tersebut. ${ }^{34}$ Sesuai dengan wawancara dengan Nur habibah, ia mengatakandalam pelaksaaan life skill perlu adanya latihan dimulai dari identifikasi kebutuhan organisasi, menetukan untuk keterampilan. Dalam mengadakan latihan dan selanjutnya kembali kepada kebutuhan untuk melihat kekuatan dan kelemahan pelaksanaan sebelumnya sehingga perlu diperbaiki atau disempurnakan dalam rangka pengembangan program organisasi. ${ }^{35}$

Dalam persatuan keluarga besar Musthafawiyah Sibanggor Jae telah diatur jadwal latihan dalam setiap kegiatan misalnya:

a) Puisi

Pelaksanaan latihan puisidilaksanakan berjadwal sesuai dengan yang telah ditetapkan dalam persatuan. Menurut Laila Nur, jadwal latihan puisi dilakukan pada hari Senin pagi jam 06.30.07.15, hari Selasa jam 09.0011.45, malam Selasa jam 20.30-22.15, dan hari Jum'at jam 09.45-12.00 Wib. ${ }^{36}$ Pernyataan yang sama juga datang dari Salwiyah, ia mengatakan bahwa latihan puisi dilakukan empat kali dalam satu minggu. Dalam latihan

\footnotetext{
${ }^{32}$ Nur Ainun, Sekretaris Persatuan KBMSJ, di Persatuan KBMSJ Pondok Pesantren Musthafawiyah Purba Baru, Wawancara, Tanggal 08 Agustus 2015.

${ }^{33}$ Elida Hannum, Penasehat Persatuan KBMSJ, Wawancara, di Persatuan KBMSJ Pondok Pesantren Musthafawiyah Purba Baru, Tanggal 14 Agustus 2015.

${ }^{34}$ Observasi, Tanggal 21 Agustus 2015 di Persatuan KBMSJ Pondok Pesantren Musthafawiyah Puba Baru.

${ }^{35}$ Nur Habibah, Wakil Humas Persatuan KBMSJ, Wawancara,di Persatuan KBMSJ Pondok Pesantren Musthafawiyah Purba Baru, Tanggal 21 Agustus 2015.

${ }^{36}$ Laila Nur, Penasehat Persatuan KBMSJ, Wawancara, di Persatuan KBMSJ Pondok Pesantren Musthafawiyah Purba Baru, Tanggal 22 Agustus 2015.
} 
itu, setiap santri bergantian tampil ke depan untuk memperaktekkan puisinya tanpa teks. ${ }^{37}$

b) Pidato

Wawancara dengan Nur Ainun mengatakan,bahwa latihan pidato di persatuan keluarga besar Musthafawiyah Sibanggor Jae dilakukan secara berjadwal, lebih lanjut ia mengatakan jadwal latihan pidato dilakukan pada hari Rabu pagi jam 06.30-07.30, malam Selasa jam 20.30-22.15, hari Selasa jam 09.00-11.45, dan hari Jum'at jam 09.45-12.00 Wib. Pernyataan yang sama dengan Salamah, ia mengatakan latihan pidato dilakukan empat kali dalam satu minggu. Dalam latihan pidato ini setiap santri bergiliran tampil ke depan untuk memperaktekkan pidato masing-masing tanpa melihat teks. Wawancara dengan Nur Kholilah, ia mengatakan dalam latihan pidato ini setiap hari Jum'at santri disuruh bergantian tiga orang tampil ke depan untuk memperaktekkan pidatonya.

c) Tilawatil Qur'an

Wawancara dengan Elida Hannum, mengatakan bahwa latihan tilawatil Quran di persatuan keluarga besar Musthafawiyah Sibanggor Jae dilakukan secara terjadwal, jadwal latihan tilawatil Quran dilakukan pada hari Sabtu pagi jam 06.30-07.30, malam Selasa jam 20.30-22.15, hari Selasa jam 09.00-11.45, hari Jum'at jam 09.45-12.00 Wib. ${ }^{38}$ Pernyataan yang sama yang datang dari Fitri Amalia, ia mengatakan latihan tilawatil Quran dilakukan empat kali dalam satu minggu. Dalam pelaksanaan kegiatan tilawatil Quran dibaca dari sebahagian ayat Alquran misalnya 1-10 ayat apabila ayatnya pendek-pendek, akan tetapi apabila ayatnya panjangpanjang di baca 1-6 ayat. ${ }^{39}$

d) Barzanji

Wawancara dengan Salamah, mengatakan latihan barzanji dilakukan secara berjadwal sesuai yang telah ditetapkan dalam persatuan keluarga besar Musthafawiyah Sibanggor Jae, jadwal latihan barzanji hari Kamis pagi jam 06.30-07.30, malam Selasa jam 20.30-22.15, hari Selasa09.00-11.45

\footnotetext{
${ }^{37}$ Salwiyah, Ketua Persatuan KBMSJ, Wawancara,di Persatuan KBMSJ Pondok Pesantren Musthafawiyah Purba Baru, Tanggal 22 Agustus 2015.

${ }^{38}$ Elida hannum, Penasehat Persatuan KBMSJ, Wawancara, di Persatuan KBMSJ Pondok Pesantren Musthafawiyah Purba Baru, Tanggal 23 Agustus 2015.

${ }^{39}$ Fitri Amaliah, Bendahara Persatuan KBMSJ, Wawancara, di Persatuan KBMSJ Pondok Pesantren Musthafawiyah Purba Baru, Tanggal 23 Agustus 2015.
} 
Wib. ${ }^{40}$ Menurut pernyataan yang sama datang dari Rizki Maulida, ia mengatakan latihan barzanji tiga kali dalam 1 Minggu, dalam pelaksanaan latihan barzanji ini anggota persatuan begantian satu-satu membaca setelah selesai saya baca. ${ }^{41}$

3) Motivasi

Pemberian motivasi, dalamkegiatan meningkatkan life skill santri sangat diperlukan karena dengan adanya motivasi santri lebih giat dan terdorong untuk menyalurkan bakat atau keterampilan masing-masing. Di dalam organisasi ini ketua dan staf persatuan sebagai motivator yang memberikan mootivasi kepada santri agar minat terhadap kegiatan meningkatkan life skillyang dilaksanakan berjalan dengan optimal.

Berdasarkan observasi motivasi intrinsik santri dapat dikatakan bagus ini bisa dilihat dari kedisiplinan santri dalam memasuki ruangan tablig dan juga kaehadiran para anggota dalammengikuti kegitan-kagiatan. ${ }^{42}$ Wawancara dengan Rizka Hayati, ia mengatakan saya memiliki kecenderungan dan motivasi yang tinggi atau keinginan yang besar terhadap keterampilan saya, sehingga saya belajar dan berusaha supaya pandai dan tampil lebih baik dari temanteman yang lain. ${ }^{43}$ Wawancara dengan Firti Maimunah, ia mengatakan apabila saya terpilih ikut serta dalam acara pertandingan yang dilaksanakan di Asrama Putri saya belajar dan berlatih sendiri agar saya bisa menampilkan yang lebih baik di samping kakak staf persatuan melatih saya. ${ }^{44}$ Wawancara dengan Siti maryam, ia mengatakan sebenarnya saya senang dalam menampilkan bakat saya, akan tetapi kadang saya malas menghapal pidato walaupun sudah di suruh oleh kakak staf persatuan. ${ }^{45}$

Dilihat dari motivasi ekstrinsik, sesuai dengan hasil wawancara dengan Laila Nur, ia mengatakan motivasi santri dalam mengembangkan life skill terlihat

\footnotetext{
${ }^{40}$ Salamah, Wakil Ketua Persatuan KBMSJ, Wawancara, di Persatuan KBMSJ Pondok Pesantren Musthafawiyah Purba Baru, Tanggal 22 Agustus 2015.

${ }^{41}$ Rizki Maulida, Wakil Sekretaris Persatuan KBMSJ, Wawancara, di Persatuan KBMSJ Pondok Pesantren Musthafawiyah Purba Baru, Tanggal 22 Agustus 2015.

${ }^{42}$ Observasi, Tanggal 04 September di Persatuan KBMSJ Pondok Pesantren Musthafawiyah Purba Baru.

${ }^{43}$ Rizka Hayati, Anggota Persatuan KBMSJ, Wawancara,di Persatuan KBMSJ Pondok Pesantren Musthafawiyah Purba Baru, Tanggal 03 September 2015.

${ }^{44}$ Fitri Maimunah, Anggota Persatuan KBMSJ, Wawancara,di Persatuan KBMSJ Pondok Pesantren Musthafawiyah Purba Baru, Tanggal 03 September 2015.

${ }^{45}$ Siti Maryam, Anggota Persatuan KBMSJ, Wawancara,di Persatuan KBMSJ Pondok Pesantren Musthafawiyah Purba Baru, Tanggal 04 September 2015.
} 
masih kurang, karena setiap dilaksanakan latihan masih banyak yang ngomongngomong dan asik berbicara dengan temannya dan tidak memperhatikan temannya yang sedang menampilkan keterapilannya. ${ }^{46}$ Wawancara denganNur Kholilah, ia mengatakan ketika santri disuruh untuk menghapal pidato masih ada sebahagian santri yang tidak menghapal karena mereka menganggap remeh dengan keterampilannya. ${ }^{47}$ Wawancara dengan, Nur Ainun, ia mengatakan ketika santri ditegor dari kesalahannya santri tidak merasa senang sehingga sulit untuk diberi nasehat. ${ }^{48}$ Wawancara dengan dengan Salamah, ia mengatakan kurangnya ketegasan kami dalam memberi hukuman bagi anggota yang tidak tampil dengan baik dalam menampilkan keterampilannya dan juga kurangnya motivasi kami dalam membangkitkan minat para anggota dalam meningkatkan keterampilan mereka. ${ }^{49}$

c. Kendala Yang dihadapi Persatuan Pelajar Keluarga Besar Musthafawiyah Sibanggor Jae dalam Meningkatkan Life Skill Santri di Pondok Pesantren Musthafawiyah Purba Baru

1) Faktor internal

Wawancara dengan Nur Habibah, ia mengatakan kurangnya kesadaran santri melaksanakan kegiata-kegiatan yang bersifat meningkatkan keterampilannya baik itu puisi, pidato, tilawatil Quran dan barzanji. ${ }^{50}$ Wawancara dengan Salmiah, ia mengatakan santri menganggap remeh denganketerampilannya sehingga ia beranggapan bahwa dirinya lebih pandai dari staf persatuannya. ${ }^{51}$ Wawancara dengan Nur Kholilah, ia mengatakan kurangnya minat dan motivasi santri dalam mengembangkan potensi yang ada pada dirinya,misalnya di hari Jum'at apabila diunjuk dalam bidang pidato dia tidak menampilkan sebagaimana yang diharapkan karena malas menghafalnya.Padahal disini mereka dituntut

${ }^{46}$ Laila Nur, Penasehat Persatuan KBMSJ, Wawancara,di Persatuan KBMSJ Pondok Pesantren Musthafawiyah Purba Baru, Tanggal 06 September 2015.

${ }^{47}$ Nur Kholilah, Penasehat Persatuan KBMSJ, Wawancara,di Persatuan KBMSJ Pondok Pesantren Musthafawiyah Purba Baru, Tanggal 06 September 2015.

${ }^{48}$ Nur Ainun, Sekretaris Persatuan KBMSJ, Wawancara,di Persatuan KBMSJ Pondok Pesantren Musthafawiyah Purba Baru, Tanggal 07 September 2015.

${ }^{49}$ Salamah, Wakil Ketua Persatuan KBMSJ, Wawancara,di Persatuan KBMSJ Pondok Pesantren Musthafawiyah Purba Baru, Tanggal 07 September 2015.

${ }^{50}$ Nur Habibah, Wakil Humas Persatuan KBMSJ, Wawancara,di Persatuan KBMSJ Pondok Pesantren Musthafawiyah Purba Baru, Tanggal 07 September 2015.

${ }^{51}$ Salmiah, Ketua Persatuan Umum KBMSJ, Wawancara,di Persatuan KBMSJ Pondok Pesantren Musthafawiyah Purba Baru, Tanggal 02 September 2015. 
untuk lebih aktif dalam mengembangkan bakat yang ada dalam dirinya. ${ }^{52}$ Apabila ditegor dari kesalahannya dia tidak merasa senang dan apabila dikasih nasehat selalu melawan.

2) Faktor Eksternal

Faktor eksternal yaitu yang berasal dari luar diri santri yaitu yang berasal dari staf persatuan. Staf persatuan adalah orang yang bertanggungjawab terhadap anggota persatuan untuk meningkatkan life skill para anggotanya. Sesuai dengan wawancara dengan Laila Nur (staf persatuan), ia mengatakan kurang mampunya kami memotivasi santri/anggota dengan semaksimal mungkin disebabkan kurangnya keterampilan dan kemampuan kami dalam melatih anggota dalam beberapa bidang yang ditetapkan dalam persatuan. ${ }^{53}$ Wawancara dengan Salmiah, ia mengatakan kurangnya perhatian dan tanggungjawab kami terhadap anggota dalam meningkatkan keterampilannya. ${ }^{54}$ Wawancara dengan Salwiyah, ia mengatakankurangnya rasa kebersamaan dan kepedulian staf persatuan dalam menyukseskan suatu program tertentu, sehingga muncul anggapan bahwa yang paling berperan penting dalam persatuan dalam meningkatkan life skill hanya ketua persatuan saja. ${ }^{55}$

\section{PENUTUP}

\section{Kesimpulan}

Dalam tubuh keluarga besar Musthafawiyah Sibanggor Jae life skill yang mereka bentuk adalah life skill yang bersifat khusus yaitu kecakapan vocasional.Life skill yang ada dalam persatuan keluarga besar Musthafawiyah Sibanggor Jae yaitu puisi, pidato, tilawatil Quran, dan barzanji. Dalam setiap kegiatan mempunyai tujuan tertentu dalam bidang puisi agar santri bisa bertutur kata dengan baik yang dapat memberi pesan kepada orang lain. Pidato ada tiga tujuan pertama, mencetak seorang pendakwah. Kedua, memupuk mental santri untuk bisa tampil berbicara di depan umum. Ketiga, mengikuti acara

\footnotetext{
${ }^{52}$ Nur Kholilah, Penasehat KBMSJ, Wawancar, di Persatuan KBMSJ Pondok Pesantren Musthafawiyah Purba Baru, Tanggal 03 September 2015.

${ }^{53}$ Laila Nur, Penasehat KBMSJ, Wawancara,di Persatuan KBMSJ Pondok Pesantren Musthafawiyah Purba Baru, Tanggal 02 September 2015.

${ }^{54}$ Salmiah, Ketua Persatuan Umum KBMSJ, Wawancara,di Persatuan KBMSJ Pondok Pesantren Musthafawiyah Purba Baru, Tanggal 02 September 2015.

${ }^{55}$ Nur Hamidah, Humas KBMSJ, Wawancara, Tanggal 02 September 2015.
} 
pertandingan yang dibuat oleh lembaga setiap pertengahan dan akhir semester.Tilawatil Quran juga ada tiga yaitu, pertama, agar santri bisa membaca Alquran dengan baik dan benar baik dalam makhorijul huruf, tajwid, dan iramanya. Kedua, mencetak Qori'ah. Ketiga, mengikuti acara perlombaan tingkat Nasional. Demikian juga barzanji mempunyai tujuan untuk meningkatkan kecintaan kepada Nabi Muhammad SAW, menyalurkan bakat para santri yang mempunyai suara bagus, untuk mempersiapkan santri agar bisa membaca barzanji dengan benar karena apabila ada acara pernikahan dalam masyarakat selalu di baca.

Untuk meningkatkan life skill santri dalam tubuh keluarga besar Musthafawiyah Sibaggor Jae ada beberapa langkah yang dilakukan yaitu: disiplin, latihan, motivasi. Pertama, disiplin santri berjalan dengan baik, hal ini dapat dilihat dari ketepatan waktu para anggota dan juga absensi dan kehadiran para anggota dalam mengikuti kegiatan-kagiatan. Akan tetapi masih ada lagi sebahagian anggota yang terlambat dalam memasuki ruangan tablig. Kedua, latihanstaf persatuan sedaya mampu mereka melatih anggotanya dalam berbagai bidang yang telah ditetapkan dalam persatuan. Dalam pelaksanaan latihan yang dilaksanakan berjadwal sesuai dengan yang telah ditetapkan dalam persatuan, dalam bidang puisi latihan setiap hari Senin pagi jam 06.30-07.15, malam Selasa jam 20.30-22.15, hari Selasa jam 09.00-11.45, dan hari Jum'at jam 09.45-12.00 WIB, dalam bidang pidato setiap hari Rabu pagi jam06.3007.15, malam Selasajam 20.30-22.15, hari Selasa jam 09.00-11.45, dan hari Jum'at jam 09.45-12.00, dalam bidang tilawatil Quran setiap hari Sabtu pagi jam 06.30.07.15, malam Selasa jam 20.30-22.15, hari Selasa, dan hari Jum'at jam 09.45-12.00 WIB, dalam bidang barzanji latihan setiap hari Kamis pagi jam 06.30-07.15, malam selasa jam 20.30-22.15, dan hari Selasa jam 09.00-11.45 WIB. Ketiga motivasi dalam memotivasi santriada beberapa cara yang dilakukan di antaranya, memberikan hadiah, penghargaan, pujian, dan hukuman.

\section{Saran-saran}

Dari hasil penelitian dan kesimpulan di atas, penulis mengajukan saransaran sebagai berikut:

a. Diharapkan kepada staf persatuan pelajar keluarga besar Musthafawiyah Sibanggor Jae agar betul-betul membimbing dan membina adek-adek persatuan dalam meningkatkan life skill agar persatuan ini lebih maju dari waktu-waktu sebelumnya. 
b. Diharapkan adanya ikatan dan kerjasama yang baik antara sesama, staf persatuan dan anggota pelajar keluarga besar Musthafawiyah Sibanggor Jae.

c. Santri/anggota hendaknya menyadari bahwa manfaat life skill dapat mengembangkan potensi yang ada dalam dirinya.

d. Seharusnya persatuan jangan hanya mengembangkan life skill vocasional aja harus mengembangkan life skill akademik

\section{Referensi}

Ahmad Fauzi, Psikologi Umum, Bandung: Pustaka Setia, 2008.

Ahmad Wahyudin, Pengembangan Model Pembelajaran Life Skill,http/www Ahmadwahyudin, diakses 05 Mei 2015 Pukul 11.00 WIB.

Anwar, Pendidikan Kecakapan Hidup (Life skils Education), Bandung: Alfabeta, 2006.

Departemen Agama RI, Mushaf Alquran dan Terjemahan, Jakarta: Pustaka AlKautsar, 2009.

Hatimah, Materi Pokok Pembelajaran Berwawasan Kemasyarakatan, Jakarta: Universitas Terbuka, 2008.

Idris, N. dkk. 1987. Pemanfaatan Media untuk Kegiatan Interaktif dalam PJJ bagi

Para Guru yang Belajar di UT. Kumpulan Makalah Seminar Nasional Pemanfaatan Jaringan Komunikasi Pendidikan. 9 - 10 September 1987.

Kunandar, Guru Profesional Implementasi Kurikulum Tingkat Satuan Pendidikan (KTSP) dan Sukses dalam Sertifikasi Guru, Jakarta: Rajawali Pers, 2009.

Nana Syaodih Sukmadinata, Metode penelitian Pendidikan, Bandung: Remaja Rosdakarya, 2012.

Saiful azwar, Metode Penelitian, Yogyakarta: Pustaka pelajar, 2004.

Sugiyono, Metode Penelitian Kuantitatif dan R\&D, Bandung: Alpabeta, 2008.

Sukarsi, Metodologi Penelitian Kompetensi dan Praktik, Jakarta: Bumi Aksar, 2008.

Suryono, Haryianto, Belajar dan Pembelajaran, Bandung: Remaja Rosdakarya, 2012.

Syafaruddin, Kepemimpinan dan Kewirausahaan, Medan, Perdana Publishing, 2010.

Tim Penyusun Kamus Pusat Bahasa, Kamus Besar Bahasa Indonesia, Jakarta: Balai Pustaka, 2005. 